\title{
Block of fear conditioning induced by habituation or extinction ${ }^{1}$
}

RUSSELL C. LEAF, ROBERT J. KAYSER, JOHN S. ANDREWS, JR., JAMES W. ADKINS AND SUSAN R. P. LEAF, WESLEYAN UNIVERSITY

Drinking suppression due to presentation of a fear $C S$ was lessened by nonreinforced presentations of the CS. Equal reduction of suppression occurred whether the nonreinforced trials preceded (habituation) or followed (extinction) conditioning. Thus, habituative nonreinforcement may be functionally, as well as operationally, similar to extinctive nonreinforcement.

Nonreinforced habituation with a stimulus that subsequently becomes a reinforced conditioned stimulus (CS) can produce a persisting partial blockage of the effectiveness of that CS(Carlton \& Vogel, 1967; Konorski \& Szwejkowska, 1952; Lubow \& Moore, 1959; Lubow, 1965; Pavlov, 1927; Ross, 1959; Spence \& Trapold, 1961). Despite such results, habituation procedures are often claimed to have only transient, rather than enduring effects (Thompson \& Spencer, 1966); and the effects of habituation are usually assumed not to involve the associative mechanisms typical of conditioning or extinction procedures, although some associative theories of habituation have been developed (Sokolov, 1960; Stein, 1966).

The present paper reports findings which suggest a new approach to studying and interpreting habituation. We compared the relative efficacy of nonreinforcement prior to conditioning (habituation) to that of nonreinforcement subsequent to conditioning (extinction), and observed that both treatments produced similar blockage of reinforcement efficacy. We therefore question the usefulness of a priori distinctions between habituation and extinction, in view of the functional similarity of the two operationally similar nonreinforcement procedures; and we suggest that available theories about extinction be used as models for theories about habituation.

Method

Subjects. The Ss were 55 adult female albino rats obtained from the Holtzman Co. (Madison, Wisc.).

Apparatus. The Ss were studied in a sound-isolated chamber with a grid floor and an audio tweeter mounted on one wall. Scrambled foot-shock unconditioned stimuli (USs) were generated by a shock source set at $85 \mathrm{~V}$ (Scientific Prototype Mfg. Corp. 4008-J). CSs were generated by driving the tweeter at five clicks/sec from the output of a click generator (Foringer \& Co., Inc. 1293) set at maximum output amplitude.

Procedure. The general procedure has been described previously (Leaf \& Leaf, 1966). Five groups of 11 randomly assigned Ss were placed individually in the chamber for $30 \mathrm{~min}$, while receiving one of five experimental treatments. Group $H$ (habituation Ss received a series of 30 nonreinforced trials of $10 \mathrm{sec}$ of clicks, followed by three trials reinforced by a $1 \mathrm{sec}$ US immediately after each CS termination. The time between onset's of click trains was $40 \mathrm{sec}$ throughout all series of stimuli for all groups. Group HC (habituation control) Ss received only the three reinforced trials at the same time after placement in the chamber as the reinforced trials for group H Ss. Group E (extinction) Ss received three reinforced trials followed by 30 nonreinforced ones. Group EC (extinction control) Ss received only three reinforced trials, beginning at the same time as for Group E. Group RC (reinforcement control) Ss recieved only three nonreinforced trials, beginning at the same timeas groups $\mathrm{H}$ and $\mathrm{HC}$. Each $\mathrm{S}$ was removed from the chamber at the end of the $30 \mathrm{~min}$ session, replaced in its home cage, and deprived of water for $24 \mathrm{~h}$.

Each $\mathrm{S}$ was returned to the experimental chamber at the end of the deprivation period and allowed to drink tap water from a bottle spout protruding into the chamber. After $30 \mathrm{sec}$ of drinking occurred, the CS was presented. The CS remained on until $10 \mathrm{sec}$ of further drinking occurred. Drinking was monitored by an electronic drinkometer which operated timers that controlled the onset of CS presentation and recorded the duration of suppression of drinking induced by the CS. Results

The group mean durations of suppression to the CS, together with the standard errors of these values are shown in Table 1. The distributions of these values were extremely heteroskedastic, as were distributions based on simple transformations of the obtained data. We made multiple two-group statistical comparisons, in view of the unavailability of a single within-group variance estimator. Outcomes of two-tailed MannWhitney $U$ tests analyses are shown in Table 1. All four groups that received conditioning suppressed drink-

Table 1. Durations of Suppression

\begin{tabular}{|c|c|c|c|c|c|c|}
\hline \multirow[t]{2}{*}{ Group } & \multirow{2}{*}{$\begin{array}{l}\text { Mean (min) } \\
\text { Suppression } \\
\text { + S.E.M. }\end{array}$} & \multicolumn{5}{|c|}{ Mann-Whitney U value when compared to Group } \\
\hline & & $\mathbf{H}$ & $\mathrm{HC}$ & $\mathrm{E}$ & $\mathbf{E C}$ & $\mathbf{R C}$ \\
\hline $\mathbf{H}$ & $1.37 \pm 0.53$ & & $20^{*}$ & 51 & - & $13 * *$ \\
\hline $\mathrm{HC}$ & $8.78 \pm 2.60$ & & & - & 47 & $1 * *$ \\
\hline $\mathbf{E}$ & $1.68 \pm 0.61$ & & & & $13^{* *}$ & $7 * *$ \\
\hline $\mathrm{EC}$ & $9.78 \pm 3.06$ & & & & & $0^{* *}$ \\
\hline $\mathbf{R C}$ & $0.10 \pm 0.03$ & & & & & \\
\hline & ${ }^{*} \mathrm{p} \overline{<} .02$ & & & & & \\
\hline & $* * p<. .002$ & & & & & \\
\hline & - not tested & & & & & \\
\hline
\end{tabular}


ing significantly more than did group RC. Marked suppression was found in Groups $\mathrm{HC}$ and $\mathrm{EC}$, which were statistically indistinguishable from each other. Groups $H$ and $E$ suppressed significantly less than did the $\mathrm{HC}$ and $\mathrm{EC}$ controls, but groups $\mathrm{H}$ and $\mathrm{E}$ did not differ. Thus, habituation and extinction were equally effective in attenuating suppression.

\section{Discussion}

In this situation habituation and extinction had quantitatively indistinguishable effects. These two nonreinforcement procedures may activate the same associative inhibitory effects.

Order and sequence of reinforcement and nonreinforcement do seem to affect learning in many other situations, including ones similar to that studied here (Konorski \& Szwejkowska, 1952). One should not, therefore, expect an exact quantitative equality of habituation and extinction effects, based solely on non reinforcement frequency, to occur in all learning situations. However, quantitative differences between habituation and extinction that might be observed in other comparisons of these two non reinforcement procedures would not necessarily infirm our main conclusion. We hypothesize that these two nonreinforcement procedures activate the same behavioral processes, but such variables as baseline states of arousal or prior conditioning may influence the magnitude of nonreinforcement-induced associative effects. If, as a general rule, even qualitative similarity between habituation and extinction should prove to be evident in a wide variety of learning situations, then a single theoretical model of the two processes would seem to be the most heuristically useful starting point for analysis of nonreinforcement effects that may depend on order of experience.

\section{References}

CARLTON, P. L., \& VOGEL, J. R. Habituation and Conditioning. $J$. comp. physiol. Psychol, 1967, 63, 348-351.

KONORSKI, J., \& SZWEJKOWSKA, G. Chronic extinction and restoration of conditioned reflexes: IV. The dependence of the course of extinction and restoration of conditioned reflexes on the "history" of the conditioned stimulus (the principle of the primacy of first training). Acta Biol. Exp., 1952, 16, 95-113.

LEAF, R. C., \& LEAF, S. R. P. Recovery time as a measure of degree of conditioned suppression. Psychol Rep., 1966, 18, 265-266.

LUBOW, R. E. Latent inhibition: Effects of frequency of nonreinforced preexposure of the CS. J. comp. physiol. Psychol., 1965, 60,454-457.

LUBOW, R. E., \& MOORE, A. U. Latent inhibition: The effect of nonreinforced preexposure to the conditional stimulus. J. comp. physiol. Psychol., 1959, 62, 415-419.

PAVLOV, I. P. Lectures on conditioned reflexes. London: Oxford Univ. Press, 1927.

ROSS, L. E. Note: Presisting inhibitory effect found in both classical and instrumerital learning situations. Psychol. Rep., 1962, 11, 691-692.

SOKOLOV, E. N. Neuronal models and the orienting reflex. In M. A. B. Brazier (Ed.) Conference on the central nervous system and behavior: III. New York: Josiah Macy, Jr., Foundation, 1960. Pp. 187-276.

SPENCE, K. W., \& TRAPOLD, M. A. Performance in eyelid conditioning as a function of reinforcement schedules and changes in them. Proc. Nat. Acad. Sci., 1961, 47, 1860-1868.

STEIN, L. Habituation and stimulus novelty: A model based on classical conditioning. Psychol Rev., 1966, 73, 352-356.

THOMPSON, R. F., \& SPENCER, W. A. Habituation: A model phenomenon for the study of neuronal substrates of behavior. Psychol. Rev., $1966,73,16-43$.

Note

1. This research was partly supported by USPHS grants MH13238 and MH13261, by a Wesleyan University faculty research grant, and by gifts of equipment and supplies from Hoffman-La Roche Inc., The Merck Institute for Therapeutic Research, Schoring Corp., The Squibb Institute for Medical Research, and Wyeth Laboratories. 